\title{
Analysis of Student Playing Activity Based on Education Domain in Public Schools of Padang City
}

\author{
Gusril $^{1 *}$, Willadi Rasyid ${ }^{2}$, M. Sazeli Rifki ${ }^{3}$, Anton Khomaini ${ }^{4}$, and Tjung Hauw Sin $^{5}$ \\ ${ }^{12345}$ Lecturer at the Faculty of Sports Science, Universitas Negeri Padang \\ *Corresponding author. Email: gusrilnasir@yahoo.com
}

\begin{abstract}
This study aims to reveal the playing activities of Padang City Elementary School students and analyze the playing activities of students based on the educational domain. The population of this study was students of the Padang City Elementary Schools. There were 200 students as a sample taken by using purposive sampling technique. The research instrument used a Likers scale questionnaire which has been tested for validity of 0.69 and reliability of 0.90 . The data analysis technique used a descriptive formula by considering the educational domain.Based on data analysis, it be concluded that: (1) The playing activities of the Padag City Elementary School students are in good category; (2) The educational domain included in the playing activities of Padang City Elementary School students are as follows: (a) The cognitive domain consists of; broaden play insight, breaded knowledge, refresh mindset, know the kinds of games (b) The psychomotor domain consists of; improve skills in playing, refresh the body, be healthy, sweat, relax, muscles, improve performance in sports; (c) Affection domain consists of: pleasing yourself, relieving stress, relieving problems at hand, comforting yourself, relieving sleepiness, eliminating boredom, not being lonely, eliminating anger, calming the mind, comforting a sad heart, increasing enthusiasm for learning, getting joy; (d) The social Domain consists of: making friends, improving relationships, recreation.
\end{abstract}

\section{Keywords: Playing Activity, Elementary School Students, Educational Values}

\section{INTRODUCTION}

Elementary School (SD) is an educational institution that provides provisions for students to be able to continue their education to a higher level. When viewed, the subjects in the SD curriculum can be grouped into general education programs, academic education programs and skills education programs. One of the subjects contained in the general education program is the subject of Physical Education, Sports and Health (PJOK): (1) Physical Education is a part of overall education that prioritizes the activities of fostering a healthy lifestyle, growth and development that is harmonious and balanced; (2) If the objectives of Physical Education have been achieved, of course the child can do play activities according to their interests and opportunities to do so. On the other hand, if the child is always restrained since childhood and not given the opportunity to play activities, then the interest in playing activities is less developed.

On the other hand, there is a tendency for parents to castrate their children not to do play activities. This is due to the wrong perception of his parents who stated that playing activities is an activity that wastes time and is less useful. When observed in everyday life, play activities are easily observed. However, in some situations, playing is difficult to distinguish from non- play activities. Schwartman (1978) in Patmonodewo states that play is not work, play is pretense, play is not something serious; play is not a productive activity. It added that working can mean playing, while sometimes playing can be experienced as working. Children who are playing can form their own world, so it is often considered real, earnest, productive and resembles real life

Play needs for children as much as for food, warmth and love. Children playing means doing a game, while play is something known as playing work. W. R. Smith in Soemitro (2000) states that play activity is a learning activity for children to adjust to the motivation that arises directly from within each individual by using the way of thinking and the whole soul is separated from the environment (8).

On the other hand, states that play activities are activities that are carried out voluntarily and based on a sense of pleasure to get pleasure from the game. Matakupan (2000) stated that playing activities are activities that are carried out seriously because they are liked. Playing activities are spontaneous activities during childhood that relate to adult activities and their environment, including imagination, the appearance of children using all feelings, hands or the whole body. 
Furthermore, Helms and Turner stated that play is a way / way for children to express the results of their thoughts, feelings, and the way they explore the world of their environment, including helping children to build social relationships between children. Children's participation encourages them to plan and evaluate activities and make choices about what they can make work or play. Playing for children is the main theme that must be done every day in their life. This activity gives a lot of time to do something he wants to do with the imagination and environment naturally (http://www.ccsd.ca/ dated 10 November 2001).

Sukintaka (2000) classifies children's games into two types, namely: (a) games with their own rules; (b) games provided by adults. Games with rules made by themselves usually they will play obediently and comply with the rules they agreed on. Whoever breaks the rules made will get ridicule from other playmates.

Soemitro (2000) classifies games by looking at the number of players and the game tools used as follows: (a) based on the number of players consisting of: team games, individual games; (b) based on the nature of the game consisting of: games to develop fantasy, thinking skills, sense of art, language, physical aspects consisting of: games to increase strength, coordination, speed, balance, and agility, endurance, dexterity, reaction; (c) based on the tools used, consisting of: games without tools and with tools.

Sukintaka (2000) classifies the games as follows: (a) based on the number of players consisting of: playing alone, playing together, playing singles, playing in teams; (b) based on the use of tools consisting of: players without tools, games using tools; (c) based on the differentiation of rules and organization consisting of: small games, big games; (d) classification based on distinctions in educational institutions consisting of: small ball games and big ball games. Small ball games such as: ball, rounders, baseball, softball, basketball, and hockey. Big ball games such as: football, volleyball, basketball, basketball and handball. The types of games played by children are very much determined by the age of the child. For certain age groups the types of games will be different from the types of games played by other age groups. This is due to the child's ability and pleasure.

Soemitro (2000) states the values contained in play activities, namely: (a) mental values consisting of: children's need for new experiences, security, selfrecognition, participation, pleasure; (b) physical values; (c) social values. Physical values contained in play activities are useful for children's growth and development in terms of physical, mental and social emotional functions. Playing activities require active and joyful movements. Playing activities that are carried out happily will affect hormones and stimulate growth. In addition, playing activities that are carried out outdoors are very good for breathing because the air is free from pollution. Children in play activities move running, jumping, crawling, pushing, and lifting.

Social values contained in play activities consist of learning to give and receive opponents to play, measuring their own strength, ability, intelligence, tenacity with the strength, ability, intelligence and tenacity of others. Children learn to recognize the strengths of their opponents, recognize their shortcomings, and recognize their opponents as playmates. If the playing situation is a group opponent, of course the child has the opportunity to learn to face the crowd. For that, children have an assessment that the group also has advantages and disadvantages.

The functions of play in education are as follows: (a) it is a means of bringing children to live together or in society; (b) the child knows his strengths, tools to play and characteristics; (c) expressing fantasy, all of its original character, performed in a dutiful and polite manner; (d) express the kinds of emotions; (e) for fun, joy and happiness; (f) fostering cooperation, obeying the rules, being honest and all of which will shape the nature of fair play.

Makmum et al (2003) stated that olympic values are philosophies, principles or teachings related to efforts to make sport and its various competitions a tool to support and promote the balanced development of humans as an important element in building a peaceful society. Who truly respects humans. It is further explained that sports activities with cultural and educational Olympism promote a way of life based on: (a) balanced development of physical, will and mind; (b) the joy found in struggle; (c) the value of education to be a good role model for other parties; (d) respect for universal ethics including tolerance, kindness, unity, friendship, non-discrimination and respect for others. The education domain consists of: cognitive, psychomotor, affection and social domains.

\section{MATERIALS AND METHODS}

This research is classified as a survey research which describes the state of an object or item when the research was conducted. Then analyzed, according to the theory which is the basis of the educational domain consisting of: cognitive, psychomotor, affection and social. This research was conducted in the primary school in Padang City which represents the city center, namely: Experimental Elementary School, West Padang District. Elementary School 05 Bungoasang represents Koto Tangah District. The populations of this study were students of the Padang City public elementary school. The sample was determined using purposive 
sampling technique and obtained 200 people representing the city center 100 students and 100 students representing the suburbs. The data were collected using a Likert scale playing activity instrument with a validity of 0.60 and a reliability of 0.86 . The data analysis technique used descriptive statistical formulas by considering the educational domain consisting of: cognitive, psychomotor, affection and social domains.

\section{RESULTS}

Based on the data analysis above, it can be described below:

\subsection{Playing Activity}

Based on the range of scores, mean, median, mode obtained shows that the playing activities of Padang City Elementary School students are in a good category. The distribution of the frequency of playing activity data can be seen in the following table:

Table 1. Playing Activity Frequency Distribution

\begin{tabular}{|c|c|c|c|}
\hline No & $\begin{array}{c}\text { Interval } \\
\text { Class }\end{array}$ & $\begin{array}{c}\text { Absolute } \\
\text { Frequency }\end{array}$ & $\begin{array}{c}\text { Relative } \\
\text { Frequency }(\%)\end{array}$ \\
\hline 1 & $88-92$ & 4 & 2 \\
\hline 2 & $93-97$ & 22 & 11 \\
\hline 3 & $98-102$ & 42 & 21 \\
\hline 4 & $103-107$ & 60 & 30 \\
\hline 5 & $108-112$ & 45 & 22,5 \\
\hline 6 & $113-117$ & 20 & 10 \\
\hline 7 & $118-122$ & 9 & 4,5 \\
\hline Total & & $\mathbf{2 0 0}$ & $\mathbf{1 0 0}$ \\
\hline
\end{tabular}

Based on the data in Table 1 above, it appears that $30 \%$ of the total respondents obtained an average score of playing activity scores, $34 \%$ obtained a score below the average price, and $37 \%$ obtained a score above the average price.

\subsection{Types of games performed by elementary school students in the city of Padang}

The types of games performed by Padang City elementary school students consist of: (a) Athletics, namely: Javelin Throw, Marathon; (b) Gymnastics; (c) Games, namely: Football, Badminton, Basketball, Volleyball, Sepaktakraw, Baseball, Handball, Table Tennis, Tennis; ; (d) Karate martial arts; (e) Small games without tools, namely: Cakbur, Hide and Seek, Play En, Fish Nets, Chase, Run, Semba Lakon; (f) Small games with tools consisting of: Rounders, Casters, Seven Stones; (g) Small games with non-ball tools, namely: Marbles, Tekong, Tug of the Mine; (h) traditional games, namely: Cikmancik (hide and seek).
Based on data analysis carried out on samples of 10 items of open-ended questions for playing activities analyzed by the percentage formula grouped into educational domains: cognitive, psychomotor, affection and social as follows:

Based on the data analysis carried out, it can be described that the educational domain contained in the playing activities of the Padang elementary school students as follows: Cognitive domain: (a) increasing the knowledge of playing with a frequency of 1; (b) add insight into playing with a frequency of 1 ; (c) train thinking patterns with a frequency of 1 ; (2) The psychomotor domain consists of: (a) healthy bodies with a frequency of 32; (b) skilled with 2 frequencies; (c) refreshing the body with a frequency of 6 ; (d) muscle relaxation with a frequency of 1 ; (e) sweating with a frequency of 11 ; (f) stronger with a frequency of $8 ;(\mathrm{g})$ agile in playing with a frequency of 1; (3) Affection domain consists of: (a) hobbies (preferences) with a frequency of 1 ; (b) eliminating saturation with a frequency of 20 ; (c) calming the mind with a frequency of 25; (d) stress relief with a frequency of 13; (e) eliminating the problems encountered with a frequency of 10 ; (f) pleases with a frequency of 30 ; (g) entertain themselves with a frequency of 14 ; (h) prevent riots with a frequency of 1; (i) relieves drowsiness with a frequency of 1 ; (j) eliminating fear with a frequency of 1; The social domain consists of: (a) recreation with a frequency of 4; (b) looking for friends with a frequency of 5; (c) increase familiarity with frequency 4; (d) so as not to be insulted with a frequency of 1 ; (e) can assemble with a frequency of 1 .

Based on the data description, the educational domain of students doing play activities emphasizes the affection domain, the psychomotor domain and the social domain, namely: so that the body is healthy, pleases the heart, calms the mind, eliminates boredom, comforts themselves, relieves stress, eliminates problems at hand, refreshes the body, expels sweat, strengthen the physical.

Students (male) educational domain in playing activities in terms of: Cognitive domain (a) understanding games; Psychomotor domain (a) so that the body is healthy with a frequency of 47 ; (b) refreshing the body with a frequency of 17; (c) physically stronger with a frequency of 18; (d) skilled in playing with a frequency of 8 ; (e) the body becomes athletic with a frequency of 1 ; (f) remove excess energy with a frequency of 1 ; $(\mathrm{g})$ physical training with a frequency of 1; Affection domain: (a) stress relief with a frequency of 10 ; (b) eliminate fatigue with a frequency of 7 ; (c) eliminating saturation with a frequency of 9 ; (d) pleasing to the heart with a frequency of 35; (d) rejoice with a frequency of 9; (e) relieving sadness with 
a frequency of 1 ; (f) increase the experience with a frequency of 2; $(\mathrm{g})$ avoid disease with a frequency of 4; (h) refreshing the mind with a frequency of 10; (i) increase enthusiasm with a frequency of 6 ; (j) increase arousal with a frequency of 1 ; (k) sweating with a frequency of 13 ; (1) seek a win with a frequency of 2 ; (m) entertaining with a frequency of 4 ; (n) satisfaction with frequency 1 ; (o) relieves headaches with a frequency of 1; (p) in order to avoid drugs with a frequency of 1; (q) get rid of annoyance with a frequency of 1; (r) eliminating feelings of fear / anxiety with a frequency of 1 ; (s) eliminates the problem encountered with a frequency of 1 ; (t) mentally train with a frequency of 1 ; Social domain: (a) recreation with a frequency of 3; (b) increase familiarity with frequency 4; (c) trapping naughty friends with a frequency of 1 ; (d) socialize a lot with frequency 6 . It can be concluded that the purpose of children (boys) to play games is to change attitudes, skills and social activities which consist of: pleasing the heart, sweating, eliminating boredom, having fun, refreshing the body, refreshing the mind, socialize a lot, nourish the body, refresh the body, strengthen physically, and are skilled in playing.

Overall, without gender differentiating, the education domain contained in playing activities of elementary school students in Padang City is viewed from the education domain as follows: increasing play insight: psychomotor domain: (1) to be healthy, stronger, sweaty, fresh, fast, smart in games, affection domain: calming the mind, eliminating boredom, relieving stress, eliminating the problems at hand, pleasing to the heart, entertaining oneself, social domain: increasing association, increasing intimacy, recreation. For more details, see the following table:

Table 2. Playing activities of the Padang City Elementary School Students in terms of the educational domain

\begin{tabular}{|c|c|c|c|c|}
\hline \multirow[t]{2}{*}{ No } & \multirow[t]{2}{*}{ Domain } & \multicolumn{2}{|c|}{ Frequency } & \multirow[t]{2}{*}{ Total } \\
\hline & & Male & Female & \\
\hline 1. & $\begin{array}{l}\text { Cognitive Domain } \\
\text { a. Increasing playing insight } \\
\text { b. Expanding knowledge } \\
\text { c. Refreshing the mindset } \\
\text { d. Knowing the kind of games }\end{array}$ & $\begin{array}{l}- \\
- \\
- \\
1\end{array}$ & $\begin{array}{l}1 \\
2 \\
1 \\
-\end{array}$ & $\begin{array}{l}1 \\
2 \\
1 \\
1\end{array}$ \\
\hline & Total & 1 & 4 & 5 \\
\hline 2 & $\begin{array}{l}\text { Psycomotor Domain } \\
\text { - Being healthy } \\
\text { - Improving skills in playing } \\
\text { - Refreshing the body } \\
\text { - Relaxing muscles } \\
\text { - Sweating } \\
\text { - Stronger Psychally } \\
\text { - Skilled in playing } \\
\text { - Incresing performance in sports } \\
\text { - Remove exess energy } \\
\text { - Exercise psychally } \\
\text { - Adding play activities }\end{array}$ & $\begin{array}{c}47 \\
- \\
17 \\
- \\
13 \\
18 \\
- \\
8 \\
1 \\
4 \\
- \\
\end{array}$ & $\begin{array}{c}32 \\
2 \\
13 \\
1 \\
11 \\
8 \\
1 \\
- \\
- \\
- \\
1 \\
\end{array}$ & $\begin{array}{c}79 \\
2 \\
30 \\
1 \\
24 \\
26 \\
1 \\
8 \\
1 \\
4 \\
1 \\
\end{array}$ \\
\hline & Total & 108 & 69 & 176 \\
\hline 3 & $\begin{array}{l}\text { Affection Domain } \\
\text { - Eliminate boredom } \\
\text { - Hobbies } \\
\text { - Calming the mind } \\
\text { - Relieve stress } \\
\text { - Eliminate the problem at hand } \\
\text { - Pleasure } \\
\text { - Self-entertaining } \\
\text { - Eliminate Sleepiness } \\
\text { - Eliminates fear/anxiety } \\
\text { - Eliminates tiredness } \\
\text { - Happy } \\
\text { - Get rid of sadness }\end{array}$ & $\begin{array}{c}9 \\
- \\
- \\
10 \\
1 \\
20 \\
4 \\
- \\
1 \\
1 \\
9 \\
2\end{array}$ & $\begin{array}{c}20 \\
1 \\
25 \\
13 \\
10 \\
30 \\
14 \\
1 \\
1 \\
- \\
- \\
-\end{array}$ & $\begin{array}{c}29 \\
1 \\
25 \\
23 \\
11 \\
50 \\
18 \\
1 \\
2 \\
1 \\
9 \\
2\end{array}$ \\
\hline
\end{tabular}




\begin{tabular}{|c|c|c|c|c|}
\hline & $\begin{array}{l}\text { - Adding experience } \\
\text { - Avoided from illness } \\
\text { - Energizing } \\
\text { - Increase passion for life } \\
\text { - Looking for victory } \\
\text { - Satisfaction } \\
\text { - Get rid of headaches } \\
\text { - Get rid of annoying } \\
\text { - Train mentally }\end{array}$ & $\begin{array}{l}2 \\
4 \\
5 \\
1 \\
2 \\
1 \\
1 \\
1 \\
1\end{array}$ & $\begin{array}{l}- \\
- \\
- \\
- \\
- \\
- \\
- \\
-\end{array}$ & $\begin{array}{l}2 \\
4 \\
5 \\
1 \\
2 \\
1 \\
1 \\
1 \\
1\end{array}$ \\
\hline & Total & 75 & 115 & 189 \\
\hline 4 & $\begin{array}{l}\text { Social Domain } \\
\text { - Adding relationship } \\
\text { - Adding familiarity } \\
\text { - not to be insulted } \\
\text { - Can gather } \\
\text { - Prevents breakage } \\
\text { - Recrreation } \\
\text { - To avoid drugs } \\
\text { - Trapping bad friends } \\
\end{array}$ & $\begin{array}{c}10 \\
4 \\
- \\
- \\
- \\
3 \\
1 \\
1 \\
\end{array}$ & $\begin{array}{l}1 \\
4 \\
1 \\
1 \\
1 \\
4 \\
- \\
-\end{array}$ & $\begin{array}{c}11 \\
8 \\
1 \\
1 \\
1 \\
7 \\
1 \\
1 \\
\end{array}$ \\
\hline & Total & 19 & 12 & 31 \\
\hline
\end{tabular}

\section{DISCUSSION}

Based on the data analysis, it can be concluded that the play activities carried out by public elementary school students in Padang City are in a good category. This is due to the large number of social media owned by elementary school students in Padang City. In addition, the socialization of elementary school students in Padang City runs well in the home and school environment.

There are also many types of games played by elementary school students because the socialization went well. Many games are based on what is seen on social media. He added that elementary school students like to do play activities because according to their characteristics they like to play and also contain an educational domain. Soemitro (2000) states the values contained in play activities, namely: (a) mental values which consist of: children's need for new experiences, security, self-recognition, participation, pleasure; (b) physical values; (c) social values. The mental values contained in play activities are as follows: (a) children become aware of their rights and learn to respect others; (b) mutual trust among playmates; (c) recognize one's shortcomings, when compared to others. The children also admitted honestly the strengths of others and controlled excessive emotional movements. In addition, children in playing activities will also recognize themselves with their dexterity, intelligence, responsibility, courtesy. By itself will increase the child's self-confidence in facing any play activities.

Physical values contained in play activities are useful for children's growth and development in terms of physical, mental and social emotional functions.
Playing activities require active and joyful movements. Playing activities that are carried out happily will affect the hormones and stimulate growth. In addition, playing activities that are carried out outdoors are very good for breathing because the air is free from pollution. Children in play activities move, run, jump, crawl, push, and lift. The movements performed affect blood circulation and respiration. Circulation works harder to pump blood throughout the body. As a consequence, the work of the heart becomes stronger and the frequency is faster. The exhalation will become deeper and faster. The impact of deep and rapid breathing causes the surface of the lung to be exposed to the air to become wider and allows for more oxygen uptake.

The social domain contained in playing activities consists of learning to give and receive opponents, measuring one's own strength, ability, intelligence, tenacity with the strengths, abilities, intelligence and tenacity of others. Children learn to recognize the strengths of their opponents, recognize their shortcomings, and recognize their opponents as playmates. If the playing situation is a group opponent, of course the child has the opportunity to learn to face the crowd. For that, children have an assessment that the group also has advantages and disadvantages. Finally, there arise in the children the tactics and strategies for dealing with the group. Another example of a group versus group situation contains social values such as: a sense of unity, togetherness, responsibility, cooperation, a feeling or an attitude of prioritizing group interests over personal interests.

The function of play in education is as follows: (a) is a vehicle for bringing children to live together or 
in society; (b) the child knows his strengths, tools to play and characteristics; (c) expressing fantasy, all of its original character, performed in a dutiful and polite manner; (d) express the kinds of emotions; $€$ for fun, joy and happiness; (f) fostering cooperation, obeying the rules, being honest and all of which will shape the nature of fair play.

\section{CONCLUSION}

The playing activities of the Padang City Elementary School students are in a good category. The types of games played by Padang City elementary school students consist of: (a) Athletics, namely: javelin throwing, marathon; (b) Gymnastics; (c) Games, namely: Football, Badminton, Basketball, Volleyball, Sepaktakraw, Baseball, Handball, Table Tennis, Tennis; ; (d) Karate martial arts; (e) Small games without tools, namely: Cakbur, Hide and Seek, Play En, Fish Nets, Chase, Run, Semba Lakon; (f) Small games with tools consisting of: Rounders, Casters, Seven Stones; (g) Small games with non-ball tools, namely: Marbles, Tekong, Tug of the Mine; (h) Traditional games, namely: Cikmancik (hide and seek).

The educational domain contained in the playing activities of the Padang City Elementary School students are as follows: (a) The cognitive domain consists of: increasing playing insight, expanding knowledge, refreshing the mindset, knowing the kinds of games (b) Psychomotor domain which consists of: improving skills in playing, refreshing the body, being healthy, sweating, relaxing muscles, skilled in playing, increasing performance in sports, sweating; (c) Affection domain which consists of: pleasing oneself, relieving stress, eliminating the problems at hand, pleasing the heart, entertaining oneself, relieving sleepiness, eliminating boredom, not being lonely, eliminating anger, eliminating boredom, calming the mind, comforting a sadness, increase passion for learning, eliminate loneliness, eliminate boredom, eliminate anger, get joy; (d) The Social Domain consists of: making friends, improving relationships, recreation.

\section{ACKNOWLEDGMENT}

This research was funded by PNBP Padang State University for the 2020 fiscal year. For this reason, thanks to the Chancellor of UNP through the Chair of LP2M and lecturers, students of FIK UNP

\section{REFERENCES}

(1) Gusril. Evaluasi Proses Belajar Mengajar Pendidikan Jasmani di Kotamadya Padang. Jurnal Pusat Pengkajian dan Pengembangan IPTEK Olahraga Menpora Volume 2 Nomor 3 Juli 2000. Jakarta : Menpora, 2000.
(2) ----------. Beberapa Faktor Yang Berkaitan Dengan Kemampuan Motorik Siswa SD Negeri Kota Padang, Disertasi Pascasarjana UNJ. Jakarta : UNJ, 2004.

(3) -------. Development of Motor in The Children, Padang: UNP Press, 2017.

(4) -----------. Kindergartens Gross Motor Learning Model Based on Playing Activities as a Basis for Character Building, International Journal of Psychological Rehabilitation, Vol.24, Issue 05, 2020

(5) Matakupan. Materi Pokok Teori Bermain, Depdkbud, 2000.

(6) Offor, Dan. Canadian Fitness andLife Style Researc Institut Program in Prevention: http/www.acsd.ca/10 November 2001.

(7) Padri. Peningkatan Hasil Belajar Penjasorkes Melalui Pendekatan Modifikasi Olahraga Peserta Didik Kelas VB Sekolah Dasar Negeri 4 Kota Pekanbaru (Tesis) . 2016.

(8) Patmonodewo, Soemiarti. Pendidikan Anak Pra Sekolah. Jakarta : Pusat Perbukuan Depdikbud Dengan Penerbit PT Rineka Cipta, 2000 Offord, Dan

(9) Syarifudin. Pengembangan Kurikulum Pendidikan Jasmani. Jakarta : UNJ, 2002.

(10) Soemitro. Permainan Kecil. Jakarta: Depdikbud, 2000.

(11) Sukintaka. Teori Bermain Untuk D2 Penjaskes. Jakarta, 2000. 